\title{
PERKEMBANGAN KONSEP PATOGENESIS ATEROSKLEROSIS
}

\author{
Poppy M. Lintong \\ Laboratorium Patologi Anatomi Fakultas Kedokteran Universitas Sam Ratulangi Manado \\ e-mail:magda_plin@yahoo.com
}

\begin{abstract}
Nowadays, the concept of the pathogenesis of atherosclerosis is called a response to injury hypothesis. This is based on the fact that atherosclerosis is a chronic inflammatory disease induced by endothelial injury (endothelial dysfunction). This chronic inflammatory disease consists of sequences of cellular and molecular responses, and is induced and accelerated mainly by endothelial injury. Furthermore, this injury causes compensatory responses which change the endothelial homeostasis, and increases the endothelial permeability and adhesion of leucocytes or platelets to endothelial cells. Many factors can trigger this endothelial injury, but the most important ones are haemodynamic imbalance and hypercholesterolemia. Besides these, vascular myocytes, together with extracellular matrix, play some significant roles in developing fatty streaks to become atheroma plaques.
\end{abstract}

Keywords: atherosclerosis, endothelial injury, lipid, chronic inflammation, vascular myocytes

\begin{abstract}
Abstrak: Konsep patogenesis aterosklerosis saat ini disebut hipotesis respons terha-dap cedera. Konsep ini mengacu pada aterosklerosis sebagai penyakit radang kronik yang diinduksi oleh cedera endotel (disfungsi endotel). Proses radang kronik pada aterosklerosis terdiri dari rangkaian respons seluler dan molekuler. Sebagai faktor utama yang dapat menginduksi dan memacu proses radang disini adalah cedera endotel. Adanya cedera endotel menyebabkan terjadinya respons kompensatorik yang mengubah homeostasis endotel serta meningkatkan permeabilitas endotel dan adhesi lekosit atau trombosit terhadap endotel. Banyak faktor dapat mencetuskan terjadinya cedera endotel namun yang terpenting adalah gangguan hemodinamik dan hiperkolesterolemia. Selain itu sel otot polos pembuluh darah juga turut berperan dalam aterogenesis yang bersama-sama dengan matriks ekstrasel mengubah fatty streak menjadi bercak ateroma.
\end{abstract}

Kata kunci: aterosklerosis, cedera endotel, lemak, radang kronis, otot polos pembuluh darah

Patogenesis aterosklerosis saat ini didasarkan pada teori hipotesis respons terhadap cedera, yang menjelaskan bahwa aterosklerosis merupakan suatu respons radang kronik dinding arteri yang dicetuskan oleh adanya cedera endotel (disfungsi endotel). ${ }^{1,2}$

Cedera endotel merupakan dasar pertama dari hipotesis respons terhadap cedera. Penyebab dari cedera atau disfungsi endotel adalah peningkatan kadar LDL dan radikal bebas yang disebabkan oleh merokok sigaret, hipertensi, diabetes melitus, faktor genetik, peningkatan kon- sentrasi plasma homosistein, infeksi mikroorganisme seperti virus herpes atau chlamydia pneumoniae, dan kombinasi dari faktor-faktor ini. Hal-hal penting yang terutama menyebabkan cedera endotel adalah gangguan hemodinamik dan hiperkolesterolemia. Hiperkolesterolemia kronik akan menyebabkan penimbunan kolesterol LDL dalam intima pada tempat dimana permeabilitas endotel meningkat. Dengan dilepaskannya radikal bebas maka LDL akan teroksidasi dan dicerna oleh makrofag untuk membentuk sel-sel busa, hal ini yang merupakan prekursor 
terhadap pembentukan bercak ateroma. ${ }^{1,2}$

Mekanisme radang berperan penting dalam memacu proses aterogenesis dengan menginisiasi, meningkatkan secara progresif, bahkan sampai menimbulkan komplikasi dari lesi-lesi aterosklerosis. ${ }^{1-3}$ Saat ini beberapa kepustakaan telah menyebutkan bahwa proses radang berperan penting pada perjalanan penyakit arteri koroner serta manifestasi aterosklerosis lainnya. ${ }^{4}$

Sel otot polos pembuluh darah juga berperan dalam aterogenesis. Sel otot polos bermigrasi dari tunika media ke tunika intima, kemudian berproliferasi dan menimbun komponen matriks ekstrasel, yang akan mengubah fatty streak menjadi suatu ateroma fibrofatty yang matang dan menyokong pertumbuhan lesi aterosklerotik menjadi progresif., ${ }^{1,2,5}$

Patogenesis aterosklerosis mencakup peran cedera endotel, radang, lemak, sel-sel otot polos, dan faktor lain seperti oligoklonal dan infeksi. Pembahasan diawali dengan menampilkan penjelasan tentang perkembangan aterosklerosis dari lesi awal sampai lesi komplikasi dan korelasi klinikopatologiknya.

\section{PERKEMBANGAN ATEROSKLEROSIS}

Perkembangan aterosklerosis telah dimulai sejak usia dini, yaitu mulai dekade pertama dengan pembentukan fatty streak yang kemudian pada dekade ketiga berubah menjadi bercak ateroma (fase praklinik). Umumnya bercak ateroma secara progresif terus menerus berubah, menjadi lebih besar dan dapat menimbulkan komplikasi bercak yang kemudian menimbulkan manifestasi klinik pada usia pertengahan dan usia lanjut (fase klinik) ${ }^{1,2}$ Lihat gambar 1.

Arteriosklerosis yang berarti pengerasan dinding arteri adalah istilah umum bagi penebalan dan hilangnya elastisitas dinding arteri. Aterosklerosis merupakan bentuk arteriosklerosis yang paling sering, dan secara karakteristik ditandai oleh adanya lesi pada intima yang disebut bercak ateroma. Bercak ini dapat menonjol ke dalam dan menutupi lumen pembuluh darah, serta dapat melemahkan tunika media dibawahnya.,

Dalam perkembangan aterosklerosis maka pembentukan bercak ateroma sepanjang dinding pembuluh darah arteri akan menyebabkan pembuluh darah itu menyempit dan mengeras. ${ }^{1-3}$

Pembentukan bercak ateroma diawali oleh adanya fatty streak, yang merupakan lesi terawal dari aterosklerosis. Fatty streak ini tidak menyebabkan penebalan dinding pembuluh darah dan tidak menyebabkan gangguan aliran darah. Biasanya fatty streak muncul sebagai bintik pipih berwarna kuning, multipel, dengan diameter $<1 \mathrm{~mm}$, yang menyatu dalam larikan panjang sekitar 1 $\mathrm{cm}$ atau lebih. Fatty streak terdiri dari sel makrofag dan sel otot polos dengan sitoplasma distensi karena mengandung lemak dan membentuk sel busa. ${ }^{1-3}$ Fatty streak merupakan prekursor bercak ateroma, yang sudah dibentuk sejak usia dini, tersering pada dekade pertama, namun tidak semuanya akan berkembang menjadi bercak ateroma atau lesi-lesi lanjut. ${ }^{1,2}$ Pembentukan bercak ateroma atau disebut juga ateromatosa, atau bercak fibrolipid (fibrous atau fibrofatty) merupakan proses utama pada aterosklerosis dan secara morfologik ditandai oleh penebalan tunika intima dan penimbunan lemak. Bercak ateroma berupa suatu lesi fokal yang meninggi pada tunika intima, lembut, warna kekuningan dengan bagian pusat mengandung lemak (terutama terdiri dari kolesterol dan ester kolesterol), ditutupi oleh suatu penutup warna putih yang keras disebut fibrous cap. Ukuran bercak ateroma bervariasi 0,3-1,5 cm, kadang-kadang menyatu sehingga membentuk massa yang lebih besar. ${ }^{1-3}$ Umumnya bercak ateroma secara progresif terus menerus berubah, menjadi lebih besar, terdapat kematian sel dan degenerasi, sintesis dan degradasi matriks ekstrasel (remodeling) dan organisasi trombus. Manifestasi klinik akibat aterosklerosis terutama disebabkan oleh karena penyem- 
pitan arteri, dan bila penyempitan $>70 \%$ maka dapat terjadi iskemik pada organ yang dipasoknya. ${ }^{3}$

Pada stadium lanjut bercak-bercak ateroma dapat mengalami komplikasi yang secara klinis sangat berarti. Komplikasi dapat berupa ruptur fokal, ulserasi, atau erosi fokal dari permukaan lumen bercak ateroma, perdarahan ke dalam bercak serta trombosis yang merupakan komplikasi yang penting dan paling ditakuti karena dapat menyebabkan penutupan arteri sebagian atau secara total, kalsifikasi, dan dilatasi aneurisma. ${ }^{1-3}$

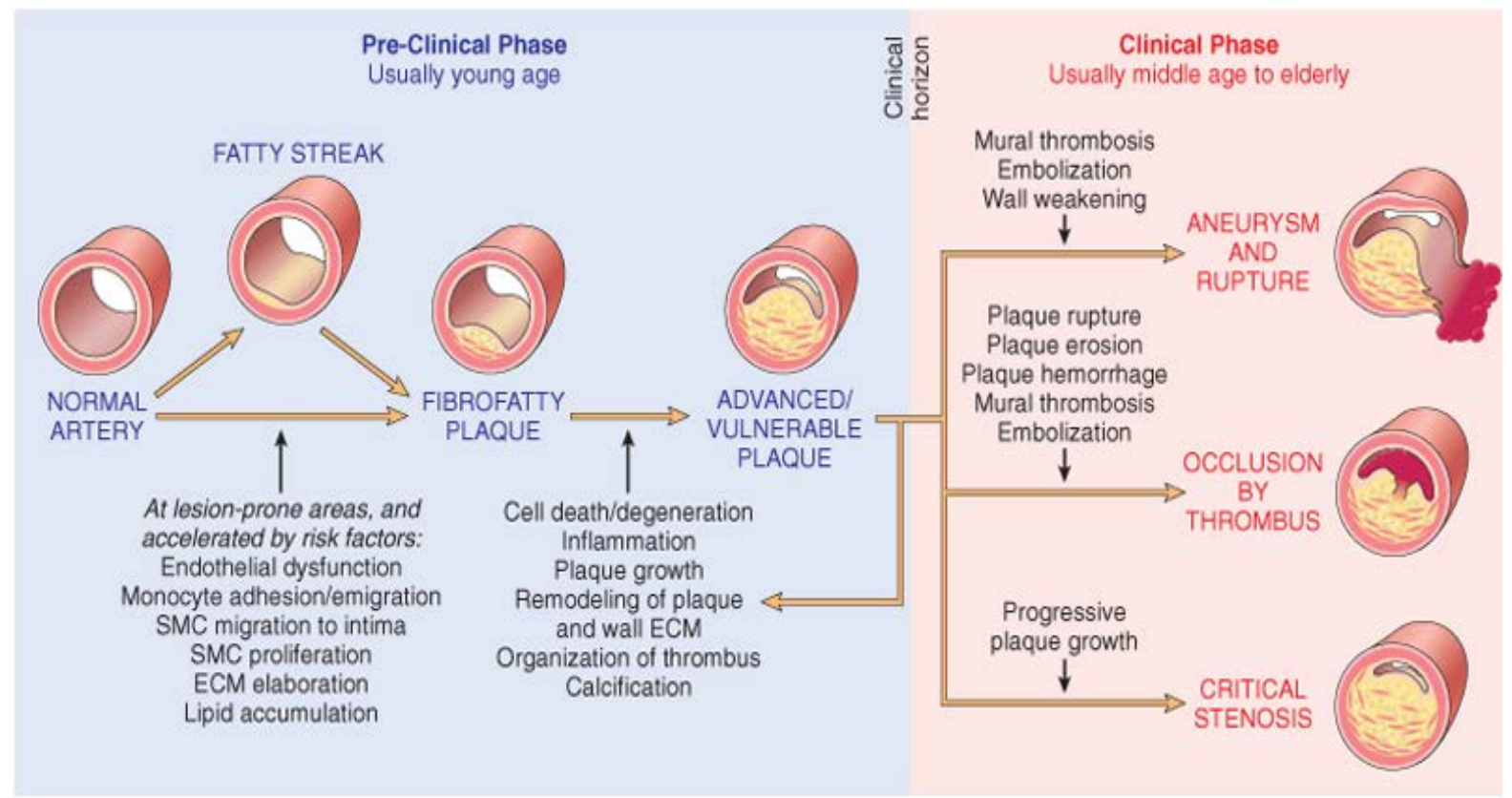

(c) Elsevier. Kumar et al: Robbins Basic Pathology 8e - www.studentconsult.com

Gambar 1.Aterosklerosis: riwayat, gambaran morfologi, patogenesis, dan komplikasi-komplikasi klinisnya

\section{PATOGENESIS ATEROSKLEROSIS}

Teori-teori lama menekankan bahwa terdapat dua hipotesis yang dapat menerangkan terjadinya aterosklerosis yaitu yang pertama proliferasi sel di dalam intima dan kedua organisasi serta pembentukan trombi yang berulang-ulang. Namun saat ini konsep patogenesis dari aterosklerosis yang dianut adalah menggabungkan kedua hipotesis lama tersebut yang dikenal dengan istilah hipotesis respons terhadap cedera (Response to injury hypothesis). ${ }^{1,2}$

\section{Hipotesis respons terhadap}

cedera menunjukkan bahwa aterosklerosis adalah suatu respons radang kronik dinding arteri yang dicetuskan oleh cedera endotel yang kemudian menjadi lesi yang progresif karena interaksi antara lipoprotein termodifikasi, makrofag, limfosit $\mathrm{T}$ dan kandungan seluler normal dinding arteri. ${ }^{1,2}$ Sejumlah pengamatan pada manusia dan hewan coba mendukung teori hipotesis respons terhadap cedera. Pada awalnya diusulkan bahwa denudasi endotel adalah langkah pertama pada proses aterosklerosis, dan hipotesis ini lebih menekankan istilah disfungsi endotel daripada denudasi endotel. Dalam proses aterosklerosis penyebab-penyebab disfungsi endotel mencakup peningkatan kadar LDL termodifikasi, radikal bebas yang disebabkan oleh merokok sigaret, hipertensi, diabetes melitus, faktor genetik, peningkatan konsentrasi plasma homosistein, infeksi mikroorganisme se- 
perti virus herpes atau chlamydia pneumoniae, dan kombinasi dari faktor-faktor tersebut. ${ }^{4}$ Dengan kata lain penyebab dari disfungsi endotel telah tercakup semua pada faktor-faktor resiko aterosklerosis. ${ }^{1-4}$ Hal-hal utama pada hipotesis respons terhadap cedera dapat dijelaskan berikut ini $^{1,2,4,5}$ : (gambar 2 dan 3)

- Perubahan paling awal yang mendahului lesi aterosklerosis berada pada sel endotel. Umumnya cedera endotel kronik mengakibatkan disfungsi endotel yang tidak memberikan gejala. Cedera endotel akan menurunkan produksi nitrik oksida (NO), meningkatkan permeabilitas pembuluh darah dan adhesi lekosit, serta berpotensi trombotik. Cedera endotel mengakibatkan terjadinya disfungsi sel endotel dan menjurus pada respons kompensatorik yang mengubah homeostasis normal sel endotel dan meningkatkan adhesi leukosit atau trombosit terhadap endotel.

- Akumulasi lipoprotein pada dinding pembuluh darah terutama LDL dengan kandungan kolesterol tinggi, diikuti oleh modifikasi lipoprotein pada lesi melalui proses oksidasi. Pada awal proses aterogenesis ekspresi sel endotel melalui ICAM-I (intercellular adhesion molekul-I) berikatan dengan macam-macam leukosit. Vascular cell adhesion molecule-1 (VCAM-I) mengikat monosit dan limfosit T. Setelah monosit melekat pada sel endotel, monosit akan beremigrasi melewati taut antar sel endotel masuk ke dalam tunika intima dan mengalami trasformasi menjadi makrofag setelah dirangsang oleh kemokin. Makrofag mencerna lipoprotein LDL yang teroksidasi membentuk selsel busa. Makrofag memproduksi interleukin-1 (IL-1) dan tumor necrosis factor (TNF) yang meningkatkan adhesi lekosit. Makrofag juga menggerakkan beberapa kemokin termasuk monocyte chemotactic protein-1 (MCP-I) yang merekrut lebih banyak lekosit ke dalam bercak ateroma. Oksigen toksik yang dihasilkan oleh makrofag menyebabkan oksidasi LDL. Partikel LDL yang tertangkap pada dinding pembuluh darah akan mengalami oksidasi progresif dan masuk ke dalam makrofag melalui reseptor scavenger pada permukaan sel membentuk peroksidase lemak dan memudahkan penimbunan ester kolesterol kemudian membentuk sel busa. Selanjutnya terjadi pembentukan fatty streak yang terdiri dari monosit lipid laden dan makrofag yang mencerna LDL yang teroksidasi bersama-sama dengan limfosit $\mathrm{T}$.

- Cedera endotel juga menginduksi sel endotel yang bersifat prokoagulan dan membentuk substansi vasoaktif seperti sitokin dan faktor-faktor pertumbuhan. Proses radang merangsang migrasi dan proliferasi sel otot polos pembuluh darah membentuk bercak ateroma. Bilamana proses radang tidak efektif untuk melawan agen penyerang maka respon radang akan berlangsung terus sehingga akan di-rekrut lebih banyak sel-sel makrofag, limfosit, dan trombosit, yang beremigrasi dari pembuluh darah masuk kedalam lesi aterosklerosis. Adhesi trombosit dan pelepasan faktor-faktor activated platelets, makrofag, atau sel-sel pembuluh darah, menyebabkan migrasi sel-sel otot polos dari tunika media masuk ke dalam tunika intima. Proliferasi sel-sel otot pada tunika intima dan matriks ekstrasel mengakibatkan akumulasi kolagen dan proteoglikan, mengubah fatty streak menjadi suatu ateroma fibrofatty yang matang dan menyokong pertumbuhan lesi aterosklerotik yang progresif.

Fatty streaks yang progresif berkembang menjadi lesi sedang dan lanjut, kemudian akan membentuk fibrous cap yang berbatasan dengan lumen pembuluh darah. Fibrous cap menutupi campuran dari lekosit, lemak dan debris seluler yang membentuk suatu pusat nekrotik. Pusat nekrotik 
terbentuk sebagai akibat pening-katan aktifitas platelet derived growth factor (PDGF), transforming growth fac-tor- $\beta$ (TGF- $\beta), I L-1$, TNF- $\alpha$, osteopontin dan penurunan degradasi jaringan ikat. ${ }^{5}$

Selanjutnya proses aterogenesis dijelaskan secara terperinci meliputi beberapa aspek dari peranan cedera endotel, radang, lemak, sel-sel otot polos, dan faktor lain seperti oligoklonal dan infeksi.

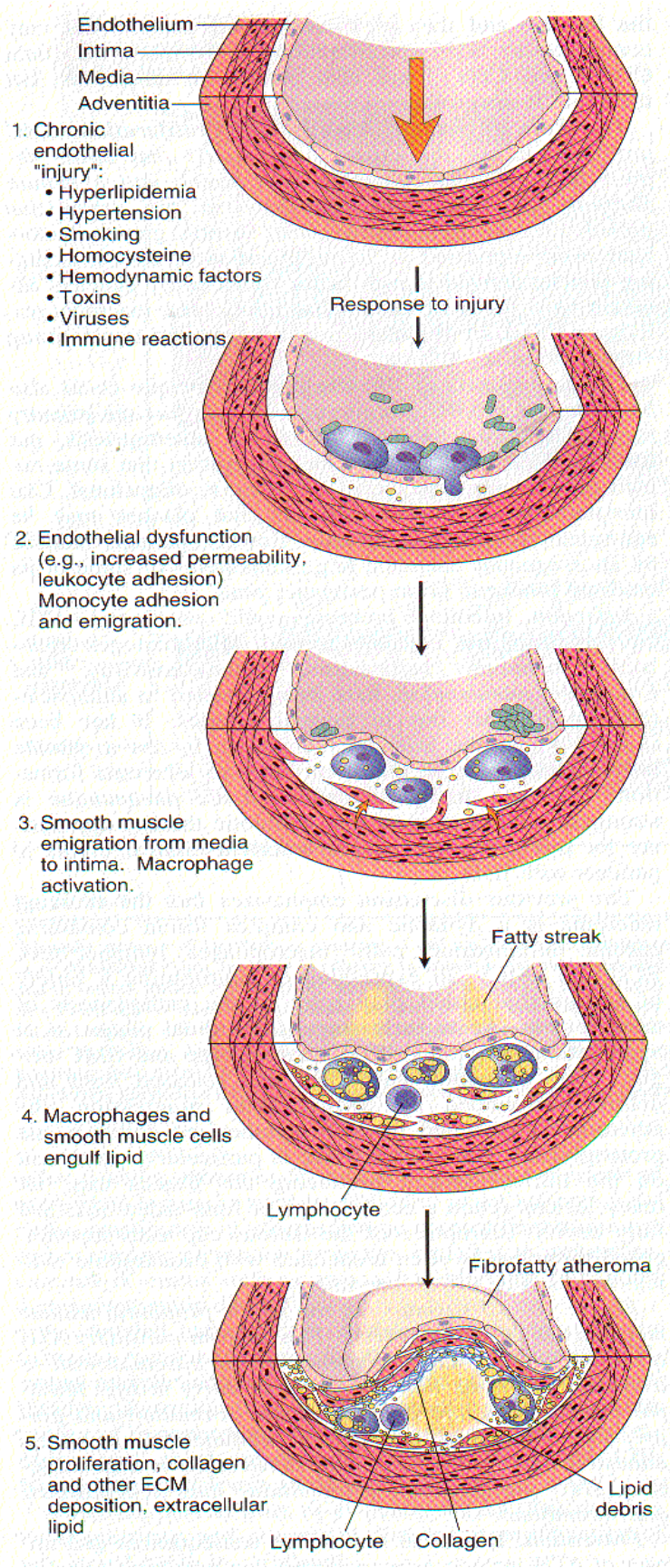

Gambar 2. Perubahan-perubahan dinding arteri pada 'hipotesis respons terhadap cedera'. 1.normal, 2.cedera endotel dengan adhesi monosit dan trombosit, 3.migrasi monosit dari lumen pembuluh darah dan otot polos tunika media ke tunika intima, 4.proliferasi sel otot polos dalam tunika intima 5.terbentuknya bercak ateroma (Kumar, Abbas, Fausto, Mitcheel. Robbins Basic Pathology. 2007.) 


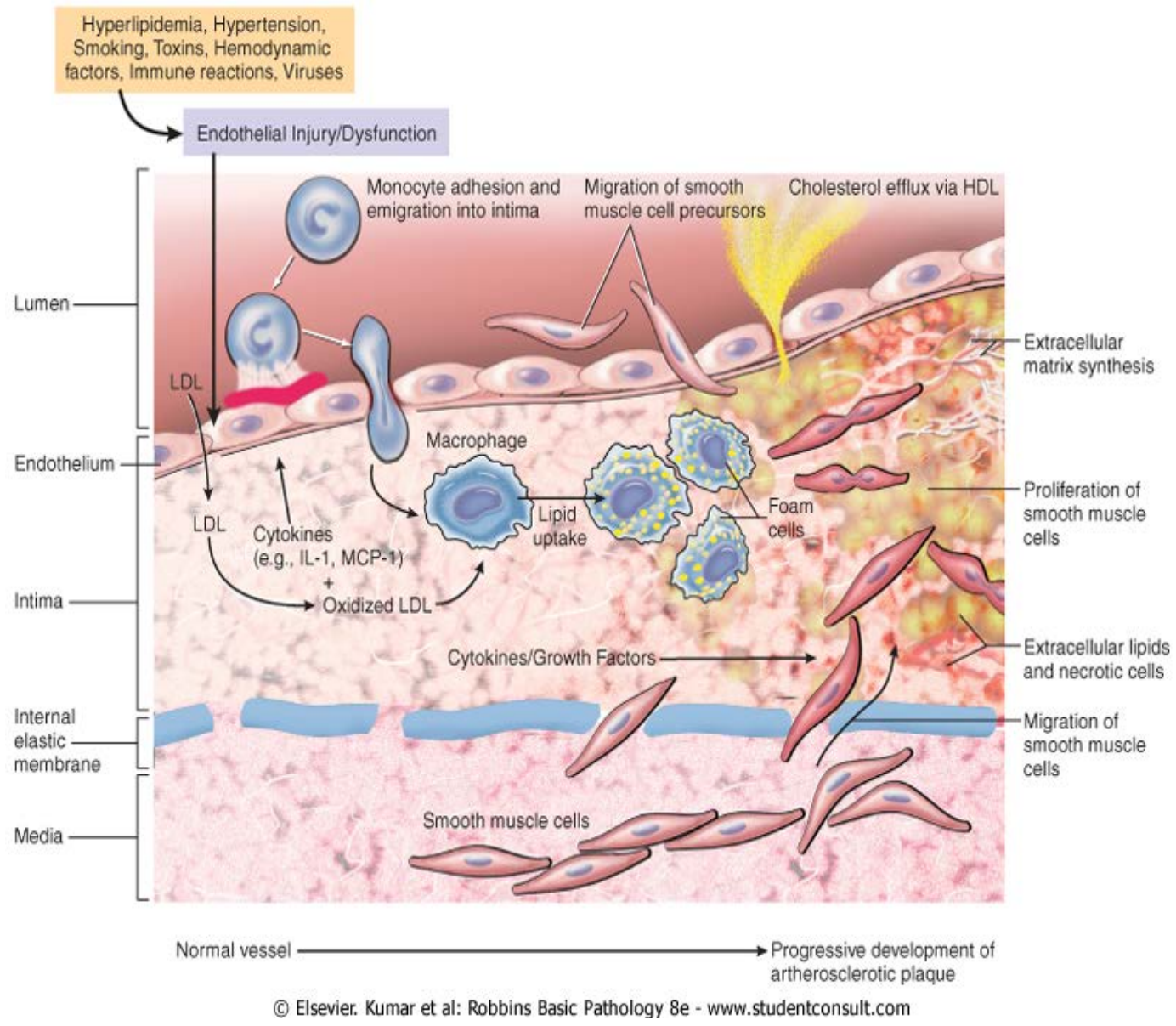

Gambar 3. Gambar skematik rangkaian interaksi seluler dari hipotesis respons terhadap cedera pada aterosklerosis. Hiperlipidemia dan faktor-faktor risiko lain menyebabkan cedera endotel, adhesi trombosit dan monosit, pelepasan faktor-faktor pertumbuhan PDGF serta memacu migrasi dan proliferasi sel otot polos. Sel-sel busa pada bercak ateroma berasal dari sel-sel makrofag dan otot polos - dari makrofag melalui reseptor very $L D L$ dan modifikasi LDL dikenal oleh scavenger receptors (LDL teroksidasi) dan otot polos. Lemak ekstrasel berasal dari lumen pembuluh darah terutama pada hiperkolesterolemia dan degenerasi sel-sel busa.

\section{Peranan cedera endotel}

Cedera endotel kronik merupakan dasar pertama dari hipotesis respons terhadap cedera. Cedera endotel diinduksi pada hewan coba melalui denudasi mekanik, adanya faktor-faktor hemodinamik, deposisi kompleks imun, iradiasi, dan bahan-bahan kimia, semuanya ini menyebabkan penebalan tunika intima; dan ditambah lagi dengan diet kolesterol yang tinggi maka terbentuk ateroma tipikal.

Pada manusia lesi awal dimulai pada tempat-tempat yang endotelnya utuh. Pada lesi awal belum terjadi denudasi endotel yang disfungsional. ${ }^{1,2}$ Perubahan pada lesi awal mencakup ${ }^{4}$ : permeabilitas pembuluh darah meningkat terhadap lipoprotein dan bahan lain yang diperantarai nitrik oksida, prostasiklin, platelet derived growth factor, angiotensin II dan endotelin, adhesi lekosit oleh aktivasi endotel melalui selektin E, integrin, dan platelet endothelial cell adhesion molecule I (PECAM-1) dan VCAM-1. Hal-hal ini akan menyebabkan migrasi leukosit masuk ke dalam dinding arteri yang dapat dicetuskan oleh LDL teroksidasi, monocyte chemotactic protein-1, interleukin-8, PDGF, macrophage colony-stimulating factor, dan osteopontin., ${ }^{1,24}$ Gangguan umum yang sering dikaitkan dengan dis- 
fungsi endotel adalah hipertensi, hiperkolesterolemia, diabetes melitus dan merokok. ${ }^{6,7}$

Penyebab disfungsi endotel pada awal aterosklerosis belum diketahui, namun terdapat faktor-faktor di dalam sirkulasi darah yang berpotensi mengganggu seperti pada perokok, homosistein, dan mungkin virus serta agen infeksi lainnya. Sitokin radang seperti TNF (tumor necrosis factor), merangsang ekspresi dari gen-gen endotel yang dapat memicu aterosklerosis. Faktor yang juga sangat penting dalam menimbulkan perubahan pada endotel adalah gangguan hemodinamik dan hiperkolesterolemia. ${ }^{1,2}$

Gangguan hemodinamik menyokong terjadinya aterosklerosis. Shear stress atau turbulensi yang tinggi atau rendah adalah penting untuk menentukan dimana tempat lesi pembuluh darah itu terjadi. Perubahan aliran darah akan mengubah ekspresi gen untuk memberi respons terhadap shear stress. Sebagai contoh gen-gen untuk intercellular adhesion molecule 1, PDGF rantai $\mathrm{B}$, dan faktor jaringan pada sel endotel, ekspresinya meningkat oleh penurunan shear stress. ${ }^{4}$ Hal ini dapat dilihat terutama pada bercak-bercak ateroma yang terjadi pada ostium pembuluh darah pada titiktitik cabang aorta abdominal dimana terdapat gangguan pola aliran darah. Daerah-daerah yang terganggu menunjukkan aliran darah turbulen dan shear stress yang rendah, dan hal ini menyokong terjadinya aterosklerosis, sedangkan aliran darah laminer yang lancar mencegah terjadinya aterosklerosis. Aliran darah laminer normal tipikal dijumpai pada daerah-daerah pembuluh darah arterial yang disebut 'lesi yang terproteksi' dimana dapat menghambat mekanismemekanisme radang yang dicetuskan oleh disfungsi endotel, apoptosis sel endotel, dan hal penting dalam hubungan dengan erosi bercak ateroma. Keadaan dengan aliran darah laminer yang lancar juga menginduksi gen-gen endotel menghasilkan antioksidan superoksida dis-mutase yang melindungi perkembangan atero- sklerosis. Jadi aliran darah laminer yang tetap lancar mencegah perkembangan lesi aterosklerosis dan hal ini disebut sebagai gen-gen ateroprotektif. ${ }^{1,2}$

Hiperkolesterolemia menyebabkan relaksasi vaskuler yang tergantung endotel menjadi terganggu. Banyak penelitian telah membuktikan bahwa disfungsi endotel dapat dicetuskan oleh kadar LDL yang tinggi. Hipertensi dapat menyebabkan penurunan vasodilator nitrik oksida (NO). Merokok menyebabkan gangguan dilatasi pembuluh darah. Penelitian akhir-akhir ini menyebutkan bahwa efek merokok disertai bertambahnya LDL yang teroksidasi berhubungan dengan perubahan keadaan redoks dinding pembuluh darah terutama pada endotel. Bertambahnya reaktivasi spesies oksigen menghambat vasodilatasi yang diperantarai nitrat oksida. Disfungsi endotel koroner berkembang cepat pada perokok dibandingkan dengan yang tidak merokok. Pada hewan coba diabetes diperlihatkan bahwa gangguan dilatasi pembuluh darah yang tergantung endotel dihubungkan dengan nitrik oksida yang tidak normal, dan pelepasan endotelin dari prostanoid konstriktor yang menghambat efek nitrik oksida. ${ }^{6}$

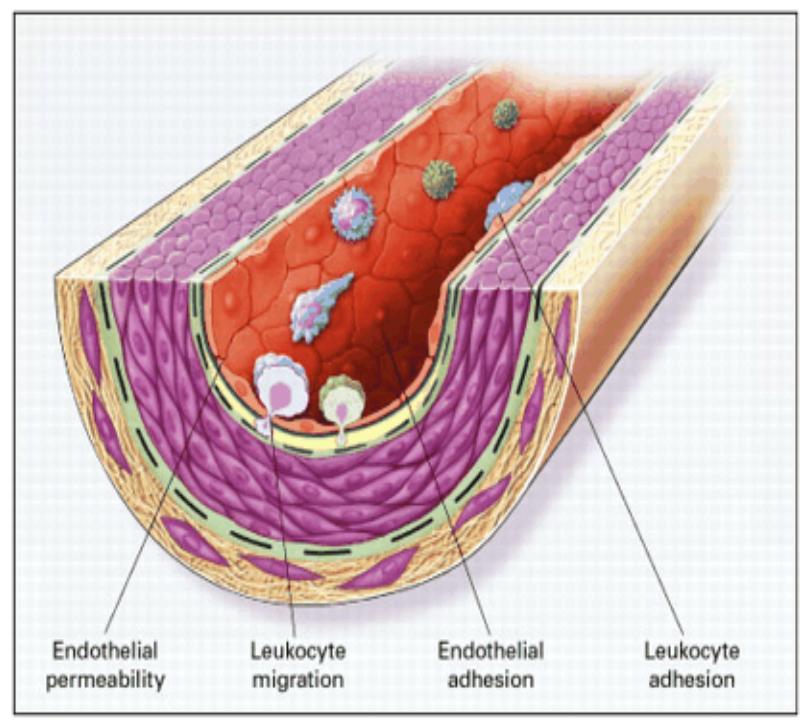

Gambar 4. Disfungsi endotel pada aterosklerosis. (Ross Russell. N.Engl.J.Med. 199 340:115-126.) 


\section{Peranan radang}

Mekanisme-mekanisme radang dapat memacu proses aterogenesis dalam hal menginisiasi, progresi, bahkan sampai menimbulkan komplikasi dari lesi-lesi aterosklerosis. Dalam proses awal aterogenesis, sel-sel endotel pembuluh darah yang diaktivasi akan mengekspresi berbagai macam leukosit pada permukaan molekul-molekul adhesi selektif sehingga menyebabkan sel-sel leukosit tersebut menggelinding sepanjang permukaan pembuluh darah. Molekul-molekul adhesi VCAM-1 (Vascular cell adhesion molecule-1) mengikat secara tepat jenisjenis leukosit monosit, dan limfosit $\mathrm{T}$ yang ditemukan pada awal ateroma pada manusia dan hewan coba. Pada saat leukosit melekat pada endotel maka kemokin yang diproduksi pada lapisan intima akan merangsang monosit untuk keluar dai pembuluh darah. Bila monosit telah melekat pada endotel maka: ${ }^{1,2,4,7}$

1. monosit bermigrasi lewat celah sel endotel dan kemudian menuju ke lapisan intima dimana hal ini paling banyak dirangsang oleh kemokin

2. monosit mengalami transformasi menjadi sel makrofag kemudian menelan lipoprotein, dan secara luas mengoksidasi LDL

Makrofag menghasilkan IL-1 (interleukin-1) dan TNF (tumor necrosis factor) yang meningkatkan adhesi lekosit. Beberapa ensim yang digerakkan oleh makrofag seperti MCP-1 (monocytechemotactic protein-1) dapat merekrut lebih banyak leukosit ke dalam bercak ateroma. ${ }^{1,2}$ Kemokin memberi repons terhadap kemotaksis dan akumulasi makrofag di dalam fatty streaks. ${ }^{4}$ Makrofagmakrofag juga menghasilkan spesies oksigen toksik yang menyebabkan oksidasi LDL dalam lesi dan melepaskan growth factor yang turut menyokong proliferasi sel-sel otot polos. Limfosit $\mathrm{T}$ (keduanya $\mathrm{CD}^{+}{ }^{+}$dan $\mathrm{CD} 8^{+}$) juga direkrut ke dalam bercak ateroma oleh adanya kemoatraktan. Reaksi silang sel-sel T dan makrofag mengakibatkan aktivasi imun seluler dan humoral yang karakteristik sebagai suatu radang kronik. Sebagai contoh sel-sel $\mathrm{T}$ mengalami sinyal-sinyal sehingga melepaskan sitokin-sitokin radang, seperti IFN- $\gamma$ dan limfotoksin, dimana pada gilirannya dapat merangsang sel-sel makrofag bersamaan dengan merangsang sel-sel endotel dan otot polos pembuluh darah. Makrofag yang diaktifkan dan sel-sel pembuluh darah intrinsik dapat melepaskan mediator-mediator fibrogenik yang mencakup bermacammacam bahan growth factor peptide, yang dapat memacu penggandaan sel-sel otot polos dan pelepasan matriks ekstrasel yang khas pada lesi aterosklerotik. ${ }^{1,2,5,7}$. Gambar 3.

\section{Peranan lemak}

Berbagai macam lemak dalam sirkulasi darah ditranspor sebagai lipoprotein yang kompleks menjadi apoprotein spesifik. Dislipoproteinemia yang terjadi karena mutasi atau beberapa gangguan lain yang mendasarinya seperti sindrom nefrotik, alkoholisme, hipotiroidisme, atau diabetes melitus menyebabkan kerusakan apoliprotein. Contoh dari lipoprotein tidak normal dapat ditemukan pada populasi dengan $^{1,2}$ :

1. peningkatan kadar kolesterol LDL

2. penurunan kadar kolesterol HDL

3. peningkatan kadar lipoprotein abnormal Lp(a)

Studi-studi pada hewan coba dan manusia menunjukkan bahwa hiperkolesterolemia menyebabkan akivasi endotel fokal arteri berukuran sedang dan besar. Infiltrasi dan retensi LDL pada tunika intima arteri menginisiasi respons radang dinding arteri. Modifikasi LDL melalui oksidasi atau ensimatik yang menyerang intima, menyebabkan pelepasan fosfolipid, yang dapat mengaktifkan sel endotel, terutama pada tempat-tempat dimana aliran hemodinamik dengan shear stress rendah. Hal ini akan meningkatkan ekspresi molekul-molekul adhesi dan gengen radang pada sel sel endotel. Dengan demikian pola hemodinamik dan akumulasi lemak pada intima dapat menginisiasi 
suatu proses radang pada arteri (Gambar 5). ${ }^{7}$

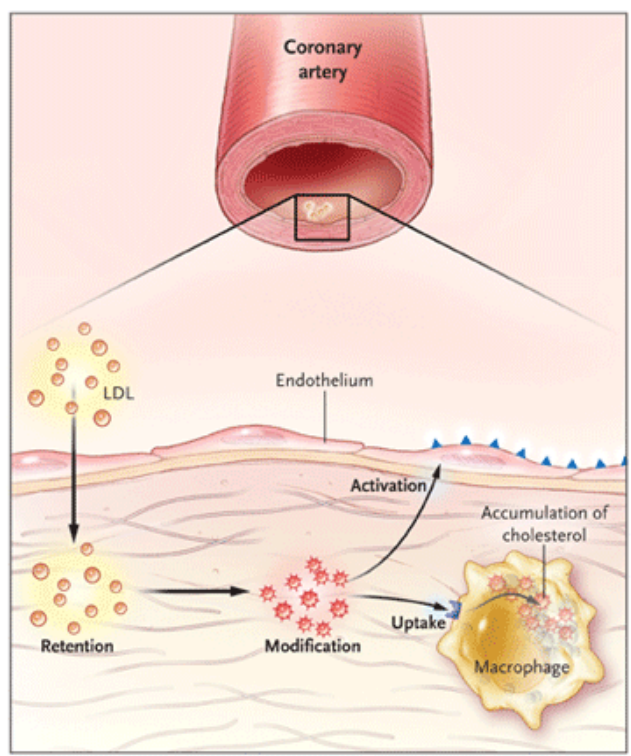

Gambar 5. Efek infiltrasi LDL menginisiasi proses radang pada dinding arteri.

(Hansson Göran K. N.Engl.J.Med. Number 16. 2005, 352:1685-1695.)

Mekanisme-mekanisme aterogenesis yang disebabkan hiperlipidemia mencakup ${ }^{1,2}$ :

- hiperlipidemia kronik, terutama hiperkolesterolemia dapat secara langsung merusak sel-sel endotel melalui penambahan produksi radikal bebas oksigen yang tidak mengaktifkan NO (vasodilator) sebagai faktor yang membuat sel-sel endotel berelaksasi dan menyebabkan bertambahnya shear stress lokal.

- hiperlipidemia kronik, menyebabkan penimbunan lipoprotein dalam intima pada tempat dengan permeabilitas endotel yang meningkat

- perubahan kimia lemak diinduksi oleh radikal-radikal bebas yang dilepaskan oleh makrofag atau sel endotel pada dinding pembuluh darah arteri dengan LDL teroksidasi (modifikasi). LDL yang teroksidasi akan:

1. Dicerna oleh makrofag melalui scavenger receptor yang ber-beda dengan reseptor LDL, dan selanjutnya membentuk sel-sel busa.

2. Meningkatkan penimbunan mo- nosit pada lesi aterosklerosis.

3. Bersifat kemotaktik terhadap monosit dan mengatur ekspresi gen untuk macrophage colony stimulating, merangsang pelepasan faktor-faktor pertumbuhan, sitokin- sitokin dan kemokin.

4. Akhirnya LDL yang teroksidasi bersifat sitotoksik terhadap sel endotel dan sel otot polos pembuluh darah sehingga menginduksi disfungsi sel endotel.

Oksidasi LDL berperan penting dalam proses aterogenesis, juga disokong oleh akumulasinya dalam makrofag pada semua stadium pembentukan bercak ateroma. Terapi antioksidan seperti $\beta$ carotene and vitamin $\mathrm{E}$ diasumsikan dapat bersifat proteksi terhadap perkembangan aterosklerosis (pada hewan coba) namun tidak efektif untuk mencegah penyakit jantung iskemik. ${ }^{1,2}$ Pada penelitian akhir-akhir ini diusulkan bahwa efek anti radang antioksidan mungkin dengan mencegah molekul adhesi terhadap monosit. Ex vivo antioksidan juga meningkatkan resistensi LDL manusia untuk teroksidasi, sesuai dengan proporsi kandungan vitamin E didalam plasma. Konsumsi vitamin E mempu-nyai korelasi terbalik dengan insiden infark jantung, dan pada percobaan klinis suplemen vitamin E mengurangi penyakit arteri koroner. $^{4}$

\section{Peranan sel otot polos pembuluh darah}

Sel-sel otot polos pada tunika media arteri dikelilingi oleh jenis jaringan ikat tertentu. Pada tunika media arteri matriks terdiri dari jaringan fibriler kolagen tipe I dan III, sedangkan pada lesi aterosklerosis terdiri dari proteoglikan bercampur dengan fibril kolagen yang tersebar. Molekul matriks penting dalam mempertahankan struktur jaringan ikat dan berperan penting dalam memandu fungsi sel. Sel-sel yang berikatan dengan matriks ekstrasel melalui reseptor integrin spesifik. Matriks metalloproteinase diproduksi oleh bermacam-macam sel yang 
berlokasi pada permukaan sel dan dicatat mendegradasi bermacam-macam matrikas ekstrasel. Matriks metalloproteinase dapat berpartisipasi dalam migrasi sel-sel otot polos. ${ }^{5,8}$

Sel-sel otot polos bermigrasi dari tunika media ke tunika intima, kemudian berproliferasi dan menyimpan komponen matriks ekstrasel, mengubah fatty streak menjadi suatu ateroma fibrofatty yang matang dan menyokong pertumbuhan lesi aterosklerotik menjadi progresif. Faktor faktor pertumbuhan yang diimplikasikan pada proliferasi sel-sel otot polos adalah PDGF/platelet derived growth factor (dilepaskan oleh platelet adherent pada suatu fokus cedera endotel, dan oleh makrofag, sel-sel endotel dan sel-sel otot polos), FGF (fibroblast growth factor) dan TGF- $\alpha$. Sel-sel otot polos juga dapat mengambil lemak yang sudah dimodifikasi dan hal ini menyokong pembentukan sel-sel busa. Sel-sel otot polos dapat menyintesis molekul-molekul matriks ekstrasel (kolagen) yang menstabilkan bercak aterosklerotik. Namun radang yang diaktifkan dan sel-sel imun pada bercak ataeroma dapat memicu apoptosis sel-sel otot polos pada tunika intima. ${ }^{1,2}$

Perkembangan ateroma terdiri dari reaksi radang kronik dan semua komponen makrofag, limfosit, sel-sel endotel, dan sel-sel otot polos yang menyokong berbagai faktor yang mempengaruhi fungsi sel. Pada stadium awal bercak ateroma pada intima merupakan kumpulan sel-sel busa yang berasal dari makrofag dan sel-sel otot polos. Beberapa daripadanya akan mati dan melepaskan lemak dan debris seluler. Pada lesi yang progresif, ateroma dimodifikasi oleh sel otot polos yang menyintesis kolagen dan proteoglikan. Jaringan ikat terutama menonjol pada permukaan intima membentuk fibrous cap tetapi beberapa lesi tetap mempunyai pusat sentral yang mengandung debris seluler dan sel-sel 'lipid laden'. Pecahnya fibrous cap dengan komplikasi terjadinya trombus sering dihubungkan dengan bukti-bukti klinis yang berakibat buruk. ${ }^{1,2}$
Trombosit yang melekat pada dinding pembuluh darah pada tempat dimana terdapat aktivasi sel endotel menyokong perkembangan lesi aterosklerotik. Ruptur atau erosi dari bercak pada lesi akan merangsang aktivasi trombosit dan agregasi pada permukaan bercak yang ruptur, dan hal ini memicu serangan akut dari trombosis arterial. Aktivasi platelet dapat juga mempengaruhui pembentukan bercak oleh pelepasan ligan adhesif, seperti selectin- $P$ yang diekspresikan pada membran trombosit dan memediasi interaksi trombosit-endotel. Sinyal dari selectin- $P$ merangsang monosit dan makrofag untuk memproduksi kemoatraktan atau faktor pertumbuhan (PDGF). ${ }^{9,10}$

\section{Faktor-faktor aterogenik yang lain:}

1. Lesi-lesi oligoklonal ${ }^{1,2}$

Hipotesis monoklonal aterosklerosis sejak tahun 1977 sudah menyebutkan bahwa berdasarkan pengamatan bercak-bercak ateroma pada manusia adalah monoklonal atau oligoklonal yang serupa dengan pertumbuhan neoplastik jinak. Hal ini mungkin diinduksi oleh bahan-bahan kimia eksogen seperti kolesterol atau beberapa produknya yang teroksidasi, atau oleh suatu virus onkogenik. Namun studistudi terakhir menunjukkan bahwa bercak klonal tetap ada, dan yang ukurannya $>4 \mathrm{~mm}$ tidak hanya pada yang mengalami aterosklerosis tetapi juga pada arteri-arteri normal, sejalan dengan kemungkinan bahwa bercakbercak aterosklerotik tidak timbul pada bercak-bercak klonal yang telah ada sebelumnya.

2. Infeksi

Infeksi dapat menyokong terjadinya aterosklerosis. $^{1,2,4,11}$ Telah diimplikasikan bahwa bakteri dan virus seperti chlamydia pneumoniae dan cytomegalovirus, keduanya dapat menginfeksi dinding pembuluh darah dan mengakibatkan infeksi yang persisten, latensi, dan rekuren. Mekanisme spesifik aterogenesis oleh bakteri dan virus masih sukar untuk dipahami. Infeksi sekun- 
der lesi aterosklerotik dapat berpotensi efek lokal dari faktor-faktor resiko yang sudah diketahui seperti hiperkolesterolemia, melalui aselerasi radang kronik atau dengan mengubah respons sel-sel dinding pembuluh darah terhadap cedera. Infeksi ekstravaskuler dapat juga mempengaruhi perkembangan lesi-lesi ateromatosa dan komplikasinya dengan jalan mengubah metabolisme lemak sistemik atau melalui mediator-mediator radang sirkulasi. Endotoksin atau sitokin proradang seperti IL-1 dihasilkan sebagai respons terhadap infeksi yang mengaktivasi sel-sel dinding pembuluh darah dan leukosit-leukosit pada lesilesi sebelumnya. Dalam hal ini, organisme yang infeksius dapat berpotensi menimbulkan komplikasi dari lesi-lesi yang sebelumya sudah terbentuk. Contoh protein c.pneumoniae pada suhu panas dapat mengaktifkan makrofag untuk menghasilkan matriks proteinase degradasi yang dapat melemahkan bercak aterosklerotik sehingga peka untuk mengalami ruptur, dapat menyebabkan terjadinya trombosis dan mencetuskan implikasi trombotik dengan mengubah keseimbangan antara koagulasi dan fibrinolisis. $^{1,2}$

\section{KESIMPULAN}

Proses radang dijumpai pada semua stadium lesi aterosklerosis. Hal utama yang menginisiasi proses radang ini adalah cedera/disfungsi endotel. Proses radang pada bercak ateroma arteri koronaria dapat merupakan predisposisi terhadap terjadinya trombosis dan infark jantung. C-Reactive Protein/CRP yang dihasil-kan selama proses radang dapat menjadi petanda untuk memprediksi risiko penyakit jantung, stroke dan penyakit arteri perifer.

\section{DAFTAR PUSTAKA}

1. Kumar, Abbas, Fausto, Mitcheel. Robbins Basic Pathology. $8^{\text {th }}$ edition. Elsevier . 2007. p343-353.

2. Schoen J Frederick. Blood Vessels. In: Kumar, Abbas, Fausto. Robbins and Cotran Pathologic Basis of disease. $7^{\text {th }}$ ed. Elsevier Saunders, 2005. p.516524.

3. Chandrasoma Parakrama, Taylor Clive R. concise Pathology $3^{\text {rd }}$ edition. 1998. Appleton \& Lange Stamford, Connecticut . p.315-322.

4. Ross Russell. Atherosclerosis - An Inflammatory Disease. N.Engl.J.Med. 199 340:115-126.

5. Rudijanto Achmad. The Role of vascular Smooth Muscle Cells on the Pathogenesis of Atherosclerosis. Acta Medica Indonesiana. Vol.XXXIX, 2007, 4: 86-91.

6. Puteh Abdul Gani. Disfungsi endotel suatu komplikasi awal atherosclerosis. JKS 2001, 1:19-25.

7. Hansson Göran K. Inflammation, Atherosclerosis, and Coronary Artery Disease. N.Engl.J.Med. Number 16. 2005, 352:1685-1695.

8. Dharmayanti Anti, Suryaatmadja Marzuki. Matrix Metalloproteinase and its Role in the Stability of the Atherosclerotic plaque. Acta Medica Indonesiana. Vol.XXXIII., 2001, 4: 149-159.

9. Davi Giovanni, Patrono Carlo. Platelet Activation and Atherotrombosis. N.Engl.J.Med. Number 14. 2008, 357:24b2-2494.

10. Massberg Steffen, Brand Korbinian, Grüner,cs. A Critical Role of Platelet Adhesion in the Initiation of Atherosclerotic Lesion Formation.. N.Engl.J.Med., number 7, 2002, 1196:887-896.

11. Underwood JCE. General and systematic pathology. $4^{\text {th }}$ edition Churchill Livingstone 2004, reprinted 2005.page.279-285. 